\title{
Farmers Knowledge about the Agricultural Insurance Scheme in Bhilwara District of Rajasthan, India
}

\author{
C. M. Yadav ${ }^{1}$, R. K. Sharma ${ }^{2}$, K. C. Nagarr ${ }^{1}$, H. L. Bugalia ${ }^{2}$ and B. G. Chhipa ${ }^{3}$ \\ ${ }^{1}$ Krshi Vigyan Kendra Bhilwara, Maharana Pratap University of Agriculture \& Technology, \\ Udaipur-313001, Rajasthan, India \\ ${ }^{2}$ College of Agriculture, Bhilwara-311001, Rajasthan, India \\ ${ }^{3}$ AICRP on Tuber crops, RCA Udaipur. (Raj), India \\ *Corresponding author
}

\section{A B S T R A C T}

\section{Keywords}

Agricultural

Insurance, Weather

Insurance,

Knowledge level,

Bhilwara, Rajasthan

Article Info

Accepted:

18 March 2020

Available Online:

10 April 2020

\begin{abstract}
The basic principle of Agricultural Insurance are that the loss incurred by the few farmers is shared by many in an area and losses incurred in bad years are compensated from resources accumulated in good years. The idea is to encourage farmers to adopt improved farming technology and agricultural practices which, though with potential of higher return could be riskier. Keeping an eye on such vital role of Agricultural Insurance the above said study has been planned to test the knowledge of farmers regarding Agriculture and Livestock Insurance Scheme which shall enable to know the abilities of the farming community that can be instrumental in providing feedback into the demand and supply system of the agriculture. The variable "knowledge" in the study has been operationally defined as the understanding or the familiarity gained through experience by the farmers about the Agricultural Insurance Scheme. It has been measured by preparing an appropriate knowledge test including the items related to various aspects of insurance schemes. A total of 204 insured farmers list was collected from both public and private sector insurance companies, being selected as respondents for the study. About $48.00 \%$ of the respondents had medium level of knowledge about the livestock insurance scheme. Whereas equal percentage of the respondents $(28.00 \%)$ had low and $(24.00 \%)$ high level of knowledge. Majority of the respondents have low level of knowledge (69.23\%) about the Weather Insurance Scheme whereas 17.30 per cent of respondents had medium level of knowledge. Only 13.46 per cent of the respondents had high level of knowledge about the weather insurance scheme. There was no relationship between the socio personal characteristics and the knowledge level of the respondents for both the weather and livestock insurance availing farmers. There should be appropriate publicity of insurance schemes so that adequate awareness is raised among the farming community further leading to insurance education of the farmers which shall enable them to decide regarding the various risk managing tools.
\end{abstract}

\section{Introduction}

Pradhanmantri Fasal Bima Yojna provides security to farmers for loss of their crop yield against low rain fall, adverse climatic condition, and other natural calamities like drought, flood, inundation, insect and disease, natural fire, lightning, unseasonal rainfall, storm, hailstorm. As per notified the premium rate of crops, farmer have to pay $2 \%$ of insured amount in Kharif, $1.5 \%$ of insured amount in Rabi and 5\% of insured amount in horticulture \& commercial crops. All farmers of Rajasthan state are covered under scheme, 
who has grown notified crop in notified area. Agricultural insurance is one method by which farmers can stabilize farm income and investment and guard against disastrous effect of losses due to natural hazards or low market prices.

Livestock Sector is an important sector of national, especially rural economy. The supplemental income derived from rearing of livestock is a great source of support to the farmers facing uncertainties of crop production, apart from providing sustenance to poor and landless farmers. The Livestock Insurance Scheme has been formulated with the twin objective of providing protection mechanism to the farmers and cattle rearers against any eventual loss of their animals due to death and to demonstrate the benefit of the insurance of livestock to the people and popularize it with the ultimate goal of attaining qualitative improvement in livestock and their products. Livestock is the main source of animal protein for the population.

It is estimated that more than $80 \%$ rural families keep livestock in their households. Contribution of animal husbandry sector to the GDP of the State has been estimated to be around $10.21 \%$. About $35 \%$ of the income of small and marginal farmers comes from dairy and animal husbandry. For promotion of the livestock sector, it has been felt that along with providing more effective steps for disease control and improvement of genetic quality of animals, a mechanism of assured protection to the farmers and cattle rearers needs to be devised against eventual losses of such animals. In this direction, the Government approved a new centrally sponsored scheme on Livestock Insurance which was implemented on pilot basis during the 10th Plan. From 2008-09 onwards, the scheme is being implemented as a regular scheme in the 100 newly selected districts till the end of 11th Five Year Plan i.e. 2011-12.

\section{Materials and Methods}

A field study conducted in Bhilwara district on the basis of the variable "knowledge" in the study has been operationally defined as the understanding or the familiarity gained through experience by the farmers about the Agricultural Insurance Scheme. It has been measured by preparing an appropriate knowledge test including the items related to various aspects of insurance schemes.

A total of 204 insured farmers list was collected from both public and private sector insurance companies, being selected as respondents for the study. Out of these 204 farmers 32 farmers were the contract farmers who had insured the cotton crop being grown in Bhilwara district of the state, 72 farmers had insured maize for the season of kharif, 2018-19 under Weather Insurance; and the rest 100 farmers had insured their cattle under Livestock Insurance Scheme. Two knowledge tests were being separately prepared for Weather Insurance Scheme and Livestock Insurance Scheme.

The items relating to the various aspects of Agricultural Insurance Schemes such as claim procedure, settlement procedure, and loss estimation of their produce were collected. The final test was being prepared by retaining the items on the basis of "Difficulty Index" and "Discriminatory Index". The items with difficulty index value ranging from 20 to 80 were retained and the items with discrimination index value of above 0.22 were included in the final knowledge test.

The reliability coefficient and the validity of the knowledge test were worked out to be 0.792 and 0.896 respectively, thus indicating the knowledge test to be considered reliable and valid. The test pertaining to the Weather Based Crop Insurance Scheme (WBCIS) consisted of 13 items and the test for 
Livestock Insurance consisted of 11 items. A score of 1 (one) was given to each correct answer of an item and zero was given to each wrong answer. The total score obtained by the respondents on all items of knowledge test was considered as the knowledge score of that respondent. The cumulative cube root method was employed to classify the respondents into different categories of knowledge level with probability proportion to the number of respondents in each category (Singh and Mangat, 2002). The knowledge level categories were formulated as low, medium and high on the basis of the above mentioned method. Other statistical tools used to analyse the data were frequency and percentage. The correlation analysis was carried out to find out the relationship between socio personal variables and the knowledge level using Pearson Product Moment Correlation Coefficient.

\section{Results and Discussion}

It is observed from Table 1 that the respondents were classified into three categories according to their age, viz young, middle and old. For the respondents insured under weather insurance little more than two fifth of the respondents were in the middle age group i.e 40.38 per cent whereas 54.00 per cent of the respondents insured under livestock insurance were under the same age group. While $30.76 \%$ and $26.00 \%$ of the respondents insured under weather and livestock insurance respectively belonged to young age group. About 28.84 per cent and 20.00 per cent of the respondents insured under weather and livestock insurance fell in the old age group. The education of the respondents was categorized into five categories as presented in Table 1. It is clear from the Table that 48.07 per cent and 56.00 per cent of the respondents covered under weather and livestock insurance respectively fell in the middle category. Whereas $38.46 \%$ and $34.00 \%$ of the respondents insured under weather and livestock insurance respectively were educated up to primary. The study findings revealed that respondents operational land holding varied between 2.5 to 25 acres. Majority $(56.73 \%)$ of respondents insured under weather insurance were operating on 5.0 - 10 acres. Whereas little more than half $(44.00 \%)$ of the respondents insured under livestock insurance were operating on 5.0 10.0 acres. The social participation of the respondents was categorized into three categories by using cumulative cube root method. The study findings that majority $(69.23 \%)$ of the respondents insured under weather insurance had low social participation but $(40.00 \%)$ of the respondents insured under livestock insurance belonged to medium social participation category. The data in Table 1 further shows that little more than half $(43.26 \%)$ of the respondents insured under weather insurance belonged to high extension contacts category where as $40.00 \%$ of the respondents insured under livestock insurance had medium extension contacts. $3.00 \%$ of the respondents insured under livestock insurance had low mass media exposure but as small as $7.69 \%$ of the respondents insured under weather insurance had low mass media exposure. Majority (78.84\% and $96.00 \%)$ of the respondents insured under weather and livestock insurance had medium mass media exposure.

\section{Knowledge level of farmers of livestock insurance}

The level of knowledge of the respondents was classified into three categories by using cumulative cube root method viz. low, medium and high regarding the various aspects of Livestock Insurance Schemes. A perusal of the data revealed (Table 2) that 48.00 percent of the respondents were under the second category i.e. medium level of knowledge. Whereas 28.00 per cent of 
respondents had low as well as 24.00 per cent high level of knowledge. These findings of the study can be attributed to the reason that the farmers availing livestock insurance are the loannee farmers for whom insurance is compulsory. These respondent farmers are well versed with all the aspects of livestock insurance scheme. The risk covered is well defined in these products with timely compensation and well systemized mode of premium collection and compensation payment. Such features of this product attract the attention of the insured farmer well towards all the aspects of the insurance scheme. Livestock Insurance coverage is generally low in terms of a voluntary product; since the non loannee farmers have no compulsion of insuring the product thus they don't know the insurance scheme and how it can give coverage in terms of any risk to the cattle reared by them. So it can be concluded that the presence of both private and public sector companies presence does not account for competition of the product as other retail products; hence less coverage (tagged with loan). The field functionaries of the line department in the state should extend the knowledge of such schemes at grass root level to the farmers so that he attains the level of making decision of risk he has and how to assure any loss in income accruing of those risks. Wide publicity of such insurance schemes and products should be done through various mass media so that every section of farming class gets aware of such risk mitigating tools to manage his farm income.

\section{Knowledge level of farmers of weather based crop insurance}

The data revealed (Table 3) that majority of the respondents have low level of knowledge $(69.23 \%)$ about the Weather Insurance Scheme whereas only $13.46 \%$ of respondents had high level of knowledge. Further the data in the Table revealed that $17.30 \%$ of the respondents had medium level of knowledge. Low level of knowledge about the insurance product indicates that the insured respondents has availed it with utter ignorance about the scheme provision. This also indicates that there is no direct link between the insurance companies and the insured farmers. The whole gamut of insurance lies at the discretion of the Financial Institution / Contracting Company. This is also one of the major reasons behind the pathetic state of insurance awareness and education. This calls for another effective channel for implementation of Weather Insurance/ Crop Insurance which first requires the adequate publicity of insurance schemes through mass media and the further leading to the insurance education of the farmers by the various stakeholders. About one fifth of the respondents have high level of knowledge since they had availed the insurance from IFFCO Tokio General Insurance Company Ltd.; which operates in the state through its wide network of cooperative structure. This clearly indicates the approach to reach the farmers at their doorstep for the popularization of agricultural insurance.

\section{Relationship between knowledge level and socio personal characteristics}

The findings clearly indicates that there is no relationship between the socio personal characteristics (age, education, operational land holding, social participation, extension contacts, and mass media exposure) and the knowledge level of the respondents who have insured their crop or livestock. The independent variables were tested for their relationship with the knowledge level as presented in Table 4. Since agricultural insurance is either compulsory or has been piloted in the state due to which there has been no probable relationship between the above cited independent variables and their knowledge level. 
Table.1 Distribution of respondents according to their socio- personal characteristics

\begin{tabular}{|c|c|c|c|c|c|}
\hline \multirow[t]{2}{*}{ Parameters } & \multirow[t]{2}{*}{ Category } & \multicolumn{2}{|c|}{$\begin{array}{l}\text { Crop/weather } \\
\text { Insu.= } 104\end{array}$} & \multicolumn{2}{|c|}{$\begin{array}{l}\text { Livestock } \\
\text { Insu.= } 100\end{array}$} \\
\hline & & No & $\%$ & No & $\%$ \\
\hline \multirow[t]{3}{*}{ Age (yrs) } & Young(25-35) & 32 & 30.76 & 26 & 26.00 \\
\hline & Middle(35-45) & 42 & 40.38 & 54 & 54.00 \\
\hline & Old(45-61) & 30 & 28.84 & 20 & 20.00 \\
\hline \multirow[t]{4}{*}{ Education } & Illiterate & 08 & 7.69 & 06 & 6.00 \\
\hline & Primary & 40 & 38.46 & 34 & 34.00 \\
\hline & Middle & 50 & 48.07 & 56 & 56.00 \\
\hline & Matric & 06 & 5.76 & 04 & 4.00 \\
\hline \multirow[t]{4}{*}{ Land (acres) } & $\begin{array}{l}\text { Marginal }(< \\
2.5)\end{array}$ & 21 & 20.19 & 03 & 3.00 \\
\hline & Small (2.5-5) & 08 & 7.69 & 11 & 11.00 \\
\hline & $\begin{array}{l}\text { Semi Medium } \\
(5.0-10.0)\end{array}$ & 59 & 56.73 & 44 & 44.00 \\
\hline & $\begin{array}{l}\text { Medium } \\
(10.0-25.0)\end{array}$ & 16 & 15.38 & 42 & 42.00 \\
\hline \multirow{3}{*}{$\begin{array}{l}\text { Social } \\
\text { Participation }\end{array}$} & Low(10-15) & 72 & 69.23 & 52 & 52.00 \\
\hline & $\begin{array}{l}\text { Medium (15- } \\
20)\end{array}$ & 26 & 25.00 & 42 & 42.00 \\
\hline & High (20-25) & 06 & 5.76 & 06 & 6.00 \\
\hline \multirow{3}{*}{$\begin{array}{l}\text { Extension } \\
\text { contacts }\end{array}$} & Low $(0-6)$ & 06 & 5.76 & 05 & 5.00 \\
\hline & Medium (6-7) & 53 & 5096 & 55 & 55.00 \\
\hline & High (7-8) & 45 & 43.26 & 40 & 40.00 \\
\hline \multirow{3}{*}{$\begin{array}{l}\text { Mass Media } \\
\text { Exposure }\end{array}$} & Low (0-5) & 08 & 7.69 & 03 & 3.00 \\
\hline & Medium (5-9) & 82 & 78.84 & 96 & 96.00 \\
\hline & High (9-10) & 14 & 13.46 & 01 & 1.00 \\
\hline
\end{tabular}

Table.2 Distribution of the respondents according to their knowledge level regarding the Livestock Insuranc Schemes (N=100)

\begin{tabular}{|l|c|c|c|}
\hline Knowledge level & Knowledge & \multicolumn{2}{|c|}{ Respondents } \\
\cline { 3 - 4 } & scores & No & $\%$ \\
\hline Low & $4-5$ & 28 & 28.00 \\
\hline Medium & $5-6$ & 48 & 48.00 \\
\hline High & $6-10$ & 24 & 24.00 \\
\hline
\end{tabular}


Table.3 Distribution of the respondents according to their knowledge level regarding the Weather Insurance Schemes $(\mathrm{N}=104)$

\begin{tabular}{|l|c|c|c|}
\hline Knowledge level & Knowledge scores & \multicolumn{2}{|c|}{ Respondents } \\
\hline Low & & No & $\%$ \\
\hline Medium & $0-3$ & 72 & 69.23 \\
\hline High & $3-4$ & 18 & 17.30 \\
\hline
\end{tabular}

Table.4 Relationship between selected Socio Personal Characteristics and Level of Knowledge

\begin{tabular}{|l|c|c|}
\hline Parameters & $\begin{array}{c}\text { ' } \mathbf{r} \\
\text { Crop/weather } \\
\text { Insu.= 124 }\end{array}$ & $\begin{array}{c}\text { ' } \mathbf{r} \\
\text { Livestock } \\
\text { Insu.= 100 }\end{array}$ \\
\hline Age & $0.029 \mathrm{NS}$ & $0.00031 \mathrm{NS}$ \\
\hline Education & $0.028 \mathrm{NS}$ & $0.003 \mathrm{NS}$ \\
\hline $\begin{array}{l}\text { Operational Land } \\
\text { Holding }\end{array}$ & $0.066 \mathrm{NS}$ & $0.014 \mathrm{NS}$ \\
\hline Social Participation & $0.139 \mathrm{NS}$ & $0.059 \mathrm{NS}$ \\
\hline Extension Contacts & $0.005 \mathrm{NS}$ & $0.012 \mathrm{NS}$ \\
\hline Mass Media Exposure & $0.056 \mathrm{NS}$ & $0.004 \mathrm{NS}$ \\
\hline
\end{tabular}

NS: Non-Significant

In Rajasthan, Agricultural Insurance has not been of much importance since risk awareness is accounted in terms of assured irrigation and high input use which makes the cotton, maize crop rotation a non-risky one. But the recent past reveals the diversification from the dominant cotton maize nonsustainable crop rotation.

If the weather insurance scheme is properly devised for specific crops which requires introduction into the crop rotation and is adequately made a part of the agricultural policy, then it can be one of alternative to motivate the farmers for assured income.

The meagre implementation of the scheme in the state is restricted to particular group of farmers or has been piloted in the state. This may be the possible reason behind the poor knowledge level of farmers about the insurance of crops and no relationship between the socio personal characteristics and their knowledge level.
This suggests appropriate publicity of insurance schemes so that adequate awareness is raised among the farming community further leading to insurance education of the farmers which shall enable them to decide regarding the various risk managing tools. Steps can be taken by both the Agricultural Universities and the State Department of agriculture to sensitize the farmers and the field functionaries regarding agricultural insurance.

\section{References}

Agriculture Insurance Company of India Ltd (2008). www.aicofindia.org accessed 2006 to 2008.

Singh R and Mangat N S (2002). Elements of Survey Sampling. Mangat Kluver Academic Publisher, London/ Dordrechl/Boston: 1135.

SBI General Insurance Company Limited (2010). 


\section{How to cite this article:}

Yadav, C. M., R. K. Sharma, K. C. Naagar, H. L. Bugalia and Chhipa, B. G. 2020. Farmers Knowledge about the Agricultural Insurance Scheme in Bhilwara District of Rajasthan. Int.J.Curr.Microbiol.App.Sci. 9(04): 2278-2284. doi: https://doi.org/10.20546/ijcmas.2020.904.272 